\title{
Isolation and selection of probiotic bacteria capable of forming biofilm for fermenting soybean meal
}

\author{
Phân lập và tuyển chọn vi khuẩn probiotic tạo màng sinh học để lên men khô \\ dầu đậu nành \\ Research article
}

Hoang, Phuong Ha*1,2; Cung Thi Ngoc Mai ${ }^{1}$; Nguyen, Thi Minh ${ }^{1}$; Do, Thi Lien ${ }^{1}$; Do, Lan Phuong ${ }^{2,3}$; Le, Thi Nhi Cong ${ }^{1,2}$

${ }^{1}$ Institute of Biotechnology, Vietnam Academy of Science and Technology; ${ }^{2}$ Graduate University of Science and Technology - VAST; ${ }^{3}$ Vietnam Academy of Traditional Medicine

\begin{abstract}
Soybean meal (SBM) is residua product after oil extraction, the SBM with $48 \%$ protein is used for poultry, cattle. The SBM contains significant amount of anti-nutritional factors. Degradation of most antigenic proteins and protease inhibitors in SBM fermented by fungal, yeast and bacterial strains. Soybean fermented products are used as feed for livestock or aquaculture. Recently, biofilm forming microorganisms were broadly applied for fermentation process using substrates such as rice bran, corn, soybean meal ... to produce probiotics. In this study, we isolated and selected beneficial microbial strains that are capable of well biofilm forming, produce digestive enzymes and resist pathogenic microorganisms to ferment of soybean meal. The result showed that, four microorganism strains including NA5.3; TB2.1; TB4.3 TB4.4 had ability of forming higher biofilm, producing digestive enzymes such as amylase, protease and cellulose. Among them, NA5.3 and TB 4.4 strains had anti-pathogenic bacteria capacity such as Vibrio parahaemolyticus; Enterococcus faecalis; Bacillus cereus and Escherichia coli. Four selected strains were checked effection of $\mathrm{pH}$, temperature, $\mathrm{NaCl}$ and bile salt concentration to their biofilm formation. The result indicated suitable conditions for forming biofilm at $\mathrm{pH} 6-8$ range; temperature range $30-37^{\circ} \mathrm{C} ; \mathrm{NaCl}$ concentration of $0-3 \%$, bile salt concentration of $0.5-2 \%$. The selected strains grew well during solid fermentation process, achieved $10^{11} \mathrm{CFU} / \mathrm{gram}$.
\end{abstract}

Khô đậu nành là sản phẩm còn lại tù quá trình ép dầu chứa tới 48\% protein thô và thuờng được sử dụng làm thức ăn cho gia cầm, gia súc. Nhưng trong khô đậu nành còn chứa một luợng đáng kể một số chất ức chế dinh duỡng, các chất ức chế này lại được phân hủy bởi quá trình lên men nhờ một số loài vi khuẩn, nấm mốc hay nấm men. Sản phẩm lên men khô đậu tuơng đuợc sủ dụng làm thức ăn cho gia cầm, gia súc hay nuôi trồng thủy sản. Trong nhĩng năm gần đây, các vi sinh vật tạo màng sinh học đã được úng dụng để lên men các co chất nhu cám gạo, ngố, khô đậu nành... tao sản phẩm probiotics. Trong nghiên cưu này, chúng tôi đã phân lạp và tuyển chọn một số vi sinh vật có lợi tạo màng sinh học cao, sinh các enzyme tiêu hóa và kháng lại một số vi khuẩn gây bệnh cho muc đích lên men khô đậu nành. Kết quả đã lự chọn được 4 chủng vi khuẩn NA5.3; TB2.1; TB4.3 TB4.4 có khả năng tạo màng sinh hoc cao, sinh các enzyme nhu amylase, protease và cellulose.Trong đó,hai chủng NA5.3 và TB4.4 có khả năng kháng lại một số vi khuấn gây bệnh nhu Vibrio parahaemolyticus; Enterococcus faecalis; Bacillus cereus và Escherichia coli. Bốn chủng vi khuẩn lụa chọn được nghiên cứu ảnh hưởng của các điều kiện lên khả năng tạo màng sinh họ của chúng, chúng thich hơp ở pH 6-8; nhiệt độ 30-37 ${ }^{\circ} \mathrm{C}$; $\mathrm{NaCl} \mathrm{0-3 \% ,} \mathrm{muối} \mathrm{mật} \mathrm{0,5-2 \% .}$ Sư dụng các chủng vi khuẩn này cho quá trình lên men rắn khô đậu tuơng, mật độ vi khuẩn sau khi lên men đạt $10^{11}$ CFU/gram.

Keywords: biofilm, fermentation, microorganism, protein, soybean meal 


\section{Introduction}

The aquaculture industry would benefit if cultured organisms conferred with enhanced growth performance, feed efficiency and disease resistance. It has been documented in animals and humans that microorganism of the gastrointestinal tract plays important roles in affecting the nutrition and health of the host. Probiotics may promote growth of bacteria such as Lactobacillus, Bacillus subtillis, Bacillus licheniformis, Enterococcus faecium, Saccharomyces cerevisiae... in the intestine and limit potentially pathogenic bacteria such as Salmonella, Vibrio, E.coli... Supplementation of biological products means beneficial effects of intestinal microbial balance on host due to these bacteria produced digestive enzymes and resisted pathogenic micro-organisms (Fuller 1989). These compounds have received heightened attention in aquaculture over the past several years (Gatesoupe 1999; Gatlin 2002; Irianto and Austin 2002). The currently recognized probiotics that may influence fish immunity, disease resistance and other usefulness such as in treating the aquatic environment is to reduce the presence of potentially pathogenic bacteria by competitive exclusion.

Prebiotics contains components such as fructo oligosaccharide (FOS), transgalacto oligosaccharide (TOS) and inulin, thus they effects on itsprobiotics (Vulevic Rastall, \& Gibson 2004). These ingredients present in rice bran, corn meal or soybean meal...

Biofilm defined as 'aggregates of microorganisms in which cells are frequently embedded in a self-produced matrix of extracellular polymeric substances (EPS) that are adherent to each other and/or a surface'. The microorganisms in the biofilm are tightly bound together, forming a stable structure. Due to the high concentration of microorganisms in the biofilm, mutual support, the ability to assimilate and metabolize will occur more quickly. Besides, this biofilm protects microorganisms from harmful external environmental factors and harsh living conditions, which can protect microorganisms for several hours or even days. Under the protection of this biofilm, bacteria can withstand a surprisingly high dose of antibiotics, (Rivas and Riquelme, 2012).

Soybean (SB) has been an important crop in Asia. The products are formed from soybeans including tofu, natto, and tempeh. This crop is used for production of soy vegetable oil. After the oil extraction from SB, the residual meal is used as a supplemental protein source for livestock, it is soy bean meal (SBM). However, SBM also contains anti-nutritional factors (ANFs), that was decrease digestibility and absorption of young animal, hence its nutrition utilization was limited (Schneeman \& Gallaher, 1986; Gu, Pan, Sun, \& Qin, 2010; Goebel \& Stein, 2011). One of prevalent ANFs is trypsin inhibitor (TI). It is a protein, which inhibits pancreatic protease, proteolysis, and the absorption of dietary proteins (Liener et al., 1988; Perez-Maldonado, Mannion, \& Farrell, 2003). The ANFs and allergens removed by fermentation, which provides other benefits. Fermented SBM (FSBM) products by using fungal and bacterial strains such as Aspergillus oryzae; Lactobacillus species and Bacillus subtilis are preferred (Yang et al., 2007). Several studies have reported numerous benefits of FSBM including degradation of allergens during fermentation by microbial proteolysis enzymes (Hirabayashi et al., 1998; Hong et al., 2004; Song et al., 2008), elimination anti-nutritive compounds and improvement nutritional value of SBM (Hong et al., 2004), decrease the incidence of diarrhea in weaned pigs (Teng, Gao, Yang, \& Liu, 2012).

The fermentation process can be a solid fermentation or a submerged fermentation and SBM can be a subject of both processes depending on its state (crude, moisture content...). Solid fermentation has many advantages on productivity and costs due to its ability to use by-products as a source of nutrients, as well as support for microbial growth (Rigo et al., 2010). Some reports have also confirmed the ability of solid fermentation which has been to upgrade the nutritional quality of SBM that can be used in aqua-feed and animal feed industries (Singh et al., 1990; Lena et al., 1997).

Vietnam has started to produce crude soybean on a large scale since 2011, and average product was over 200 tons of crude SB per year. The huge amount of SBM after the extraction was a challenge for the plant. These studies show that using SBM as a substrate for fermentation of probiotic microorganisms and provide a source of nutritious food for domestic animals. Utilizing agricultural wastes containing nutrients for the purpose producing safe biological preparations is a completely new strategy

In this study, we selected beneficial microbial strains that are not only capable of well biofilm forming, but also produce digestive enzymes and resist pathogenic microorganisms. These beneficial microbial will be used for SBM fermentation as a food for aquaculture.

\section{Material and method}

\subsection{Samples}

Shrimp gut samples were collected from aquaculture ponds in Nghe An and Soc Trang provinces.

\subsection{Culture media}

De Man Rogosa Sharpe (MRS) (gram/L): tryptone 10, glucose 20 , beef peptone 10 , yeast extract 5 , Tween-80 1 $\mathrm{mL}, \mathrm{K}_{2} \mathrm{HPO}_{4} 2$, sodium acetate 5, sodium citrate 2, $\mathrm{MgSO}_{4}$ 0.2, $\mathrm{MnSO}_{4} 0.05$ at pH: 6-6,5 (Yuan L, 2017). Media was autoclaved at $0.15 \mathrm{MPa}$ for $20 \mathrm{~min}$.

\subsection{Methods}

\section{Isolation}

Shred shrimp intestine were serially diluted to $10^{-1}, 10^{-2}$, $10^{-3}, 10^{-4}, 10^{-5}$ and $10^{-6}$ in penicillin vials. Subsequently, water sample from each vial was cultured on petri dishes of MRS media by spread plating technique. Then, bacteria were incubated at $37 \pm 2^{\circ} \mathrm{C}$ in 1-2 days. After bacterial colonies could be observe by naked eyes, single colonies were sub - cultured on medium by streak plating tech- 
nique. Subcultures were then incubated at the same conditions for $1-2$ days before further experiments (Nguyen Lan Dung, 1983).

\section{Enzyme analysis}

Determination of enzymatic activity of $\alpha$-amylase, cellulose enzyme, protease enzyme by Agar well diffusion assay (Hong Ha et al., 2005; Jayasree et al., 2006); Culture medium was supplemented with phosphate buffer $(\mathrm{pH}=7) 100 \mathrm{Mm}$; agar 1\%; or 1\% starch (for the enzyme $\alpha$-amylase); or CMC $1 \%$ (for cellulose enzymes); or $0.1 \%$ casein (for protease enzyme).

Protocol: Adding $100 \mu \mathrm{l}$ of culturing microorganisms into wells on agar plates; the wells containing were positive control and the wells containingmedium solutions were negative control. After 16 -24 hours of static culture at room temperature $\left(\approx 25^{\circ} \mathrm{C}\right)$, pour a solution of lugol reagent to fill the agar plate. After 1 hour rinsing with distilled water and observing $\alpha$-amylase enzyme or cellulose enzyme that dissolved the substrate and makes the light rings on the green agar dish. With the protease enzyme to use $0.1 \%$ black amido reagent $10 \mathrm{~B}$ diluted in methanol, acetic acid and distilled water at a ratio of 3: 1: 6 , or in solution of $7 \%$ acetic acid. Protenase enzymes that dissolved the substrate and makes the light rings on the brown agar dish. The diameter $(\mathrm{D}-\mathrm{d}=\mathrm{mm})$ of the light ring was activity of the enzyme.

\section{Resist the pathogenic microorganisms}

Resist the pathogenic microorganisms (Vibrio parahaemolyticus; Enterococcus faecalis; Bacillus cereus and Escherichia coli) of five isolated strains by Agar well diffusion assay (Hong $\mathrm{Ha}$ et al., 2005; Jayasree et al., 2006).

Protocol: Spreading $0.1 \mathrm{ml}$ of culture solution of pathogenic microorganism on a MRS media dish. Adding 0.1 $\mathrm{ml}$ of cultured sollution of each probiotic strain into each well on the agar disk and culturing at $37^{\circ} \mathrm{C}$ for 24 hours. Examination of antibacterial activity by observation of growth inhibition ring of pathogenic bacteria on agar dish.

\section{Biofilm forming analysis}

Bacterial isolates were cultured in MRS liquid medium in a shaker incubator $\left(200 \mathrm{rpm}, 37^{\circ} \mathrm{C}\right)$ for $1 \mathrm{day}, 1 \mathrm{ml}$ of culture media was transferred into aseptic Eppendorf tubes and cultured for 1 day $\left(150 \mathrm{rpm}, 37^{\circ} \mathrm{C}\right)$. Subsequently, all culture media were propagated into another set of Eppendorf tubes for bacterial growth determination (measure absorbance at OD600). The original tubes were stained with $1 \mathrm{ml}$ crystal violet $1 \%$ for 20 minutes at room temperature. After staining, sample tubes were washed gently with distilled water, $1 \mathrm{ml}$ of ethanol $70 \%$ was added to dissolve adhered crystal violet. Absorbance was measured at OD570 nm (Mohamed et al., 2004).

\section{Effect of pH on biofilm formation of isolates}

The isolates were cultured on MRS medium at different $\mathrm{pH}(2,4,6,7,8$ and 10) and determined their biofilm formation on these $\mathrm{pH}$ ranges.

\section{Effect of temperature on biofilm formation of isolates}

The isolates were cultured on MRS medium at different temperatures $(5,10,15,20,25,30,37,40$ and 45) and determined their biofilm formation on this temperature

\section{Effect of salt $(\mathrm{NaCl})$ on biofilm formation of isolates}

The isolates were cultured on MRS medium at different concentration $\mathrm{NaCl}(\%)(0,1,2,3$, and 4)

\section{Effect of bile salt on biofilm formation of isolates}

The isolates were cultured on MRS medium at different concentration $\mathrm{NaCl}(\%)(0.5,1,1.5$ and 2$)$

\section{Fermentation of soybean mean}

Bacteria biomass was breeding up to $10^{8} \mathrm{CFU} / \mathrm{L}$ and mixed at the ratio of 2: 4: 1 (w: v: v). For instant, 100 grams of substrate (soy bean meal) $+200 \mathrm{ml}$ medium + $50 \mathrm{ml}$ bacteria biomass. This product are fermented for 2 days at $37^{\circ} \mathrm{C}$ and finally to dry the product with $15-20 \%$ moisture at $40^{\circ} \mathrm{C}$.

\section{Results and discussion}

\subsection{Isolate and selected the bacteria strains that produce digestive enzymes}

The water and sediment samples were used for isolated and cultured on petri dishes and selected 16 single colonies on MRS media that was different the phenotype (Table 1). The results were shown in Table 1 . There are 9 bacteria strains NA1.1; TB1.1; TB2.1; TB2.3; TB2.4; TB4.3; TB 4.4; TB 5.1 and TC 1.1, that produce digestive enzymes such as amylase, protease and cellulose. These strains were selected to test biofilm formation. Illustrative images of typical strains are shown in Figure 1;2; 3.

Table 1. produce digestive enzymes of isolated bacteria

\begin{tabular}{|c|c|c|c|c|}
\hline \multirow[t]{2}{*}{$\mathrm{N}^{\mathrm{o}}$} & \multirow[t]{2}{*}{ strains } & \multicolumn{3}{|c|}{ activity of the enzymes } \\
\hline & & $\begin{array}{c}\alpha-\text { am- } \\
\text { ylase } \\
D-d \\
(\mathrm{~mm}) \\
\end{array}$ & $\begin{array}{c}\text { Cazein } \\
\text { protease } \\
\mathrm{D}-\mathrm{d} \\
(\mathrm{mm})\end{array}$ & $\begin{array}{l}\text { Cellu- } \\
\text { lose } \\
\text { D -d } \\
(\mathrm{mm})\end{array}$ \\
\hline 1 & NA1.1 & & & \\
\hline 2 & NA 5.3 & 30 & 26 & 29 \\
\hline 3 & NA 5.4 & & & \\
\hline 4 & TB 1.1 & 24 & 25 & 24 \\
\hline 5 & TB 2.1 & 23 & 24 & 24.5 \\
\hline 6 & TB 2.3 & 21 & 38 & 32 \\
\hline 7 & TB 2.4 & 21 & 33 & 30 \\
\hline 8 & ТВ 4.3 & 25 & 23 & 29 \\
\hline 9 & TB 4.4 & 26 & 27 & 30 \\
\hline 10 & TB 5.1 & 21 & 25 & 24 \\
\hline 11 & TC 1.1 & 18 & 26 & 25 \\
\hline
\end{tabular}




\begin{tabular}{ccccc}
$\mathrm{N}^{\mathrm{O}}$ & strains & \multicolumn{3}{c}{ activity of the enzymes } \\
\cline { 3 - 5 } & & $\begin{array}{c}\alpha-\text { am- } \\
\text { ylase } \\
\text { D -d } \\
(\mathrm{mm})\end{array}$ & $\begin{array}{c}\text { Cazein } \\
\text { protease } \\
\text { D -d } \\
(\mathrm{mm})\end{array}$ & $\begin{array}{c}\text { Cellu- } \\
\text { lose }\end{array}$ \\
$\begin{array}{ccccc}\mathrm{D}-\mathrm{d} \\
(\mathrm{mm})\end{array}$ \\
\hline 12 & A1 & 18 & 0 & 0 \\
13 & A2 & 0 & 0 & 0 \\
14 & P3 & 0 & 0 & 0 \\
15 & P4 & 21 & 0 & 0 \\
16 & P5 & 19 & 0 & 0
\end{tabular}

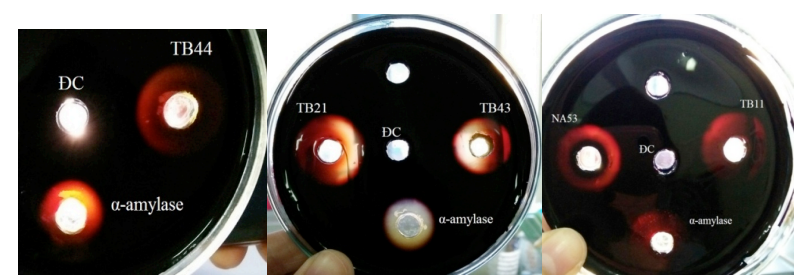

Figure 1. Produce digestive enzyme amylase of TB 1.1; TB 2.1; TB 4.3; TB4.4 and NA 5.3

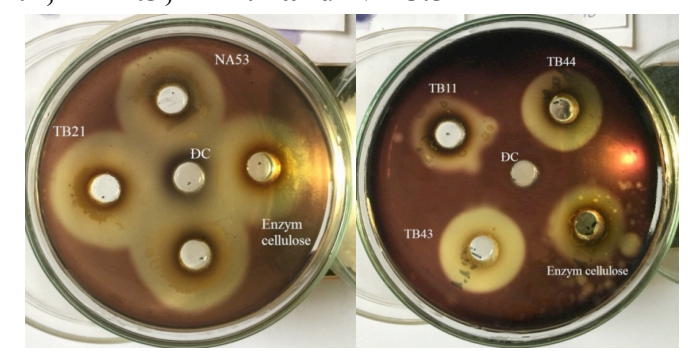

Figure 2. Produce digestive enzyme cellulose of TB 1.1; TB 2.1; TB 4.3; TB4.4 and NA 5.3

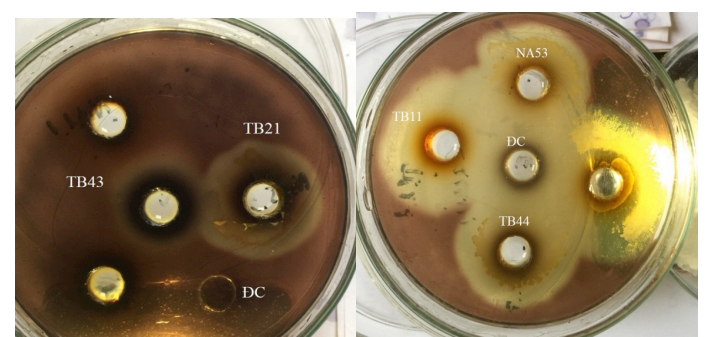

Figure 3. Produce digestive enzyme protease of TB 1.1; TB 2.1; TB 4.3; TB4.4 and NA 5.3

\subsection{Forming biofilm of selected bacteria}

For the purpose of selecting beneficial microbes not only for the production of digestive enzymes but also for biofilm formation, selected strains were tested for biofilm formation, the results are shown in Figure 4.

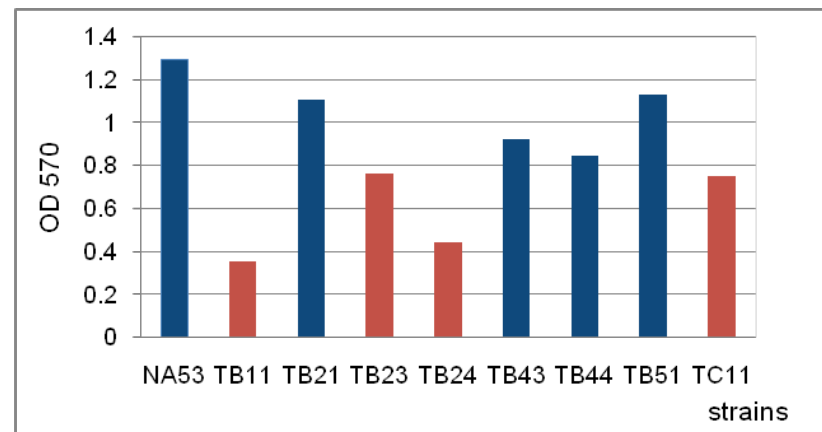

Figure 4. Biofilm forming capacity of the isolates
Although all achieved bacteria could form biofilm, from Fig.1, NA5.3 strain was the best, then four isolates of TB 5.1; TB2.1; TB 4.3; and TB 4.4 were able to form the biofilm higher than TB2.3; TC 1.1; TB 2.4 and TB1.1.

\subsection{Inhibition or resist the pathogenic microorganisms}

Based on the result from table 1 and Fig. 1, five isolated NA5.3; TB1.1; TB2.1; TB4.3 and TB 4.4 were tested for resistance capacity the pathogenic microorganisms (Table 2). Only three isolated NA5.3; TB1.1; TB 4.4 has antipathogenic bacteria activity (Table 2 ) (Fig $5 ; 6 ; 7 ; 8$ ). In which NA5.3 strain had the best activity, following TB 4.4 strain. They were resistant to four pathogenic bacteria of $V$. parahaemolyticus; E. faecalis; B. cereus and E. coli. Although TB 2.1 strain was not resistant to pathogenic bacteria but it had the higher biofilm formation, so four strains NA5.3; TB2.1; TB4.3 TB4.4 were selected for studying on effect of physiological and biochemical conditions on their biofilm formation.

Table 2. Resistance the pathogenic microorganisms of isolated bacteria

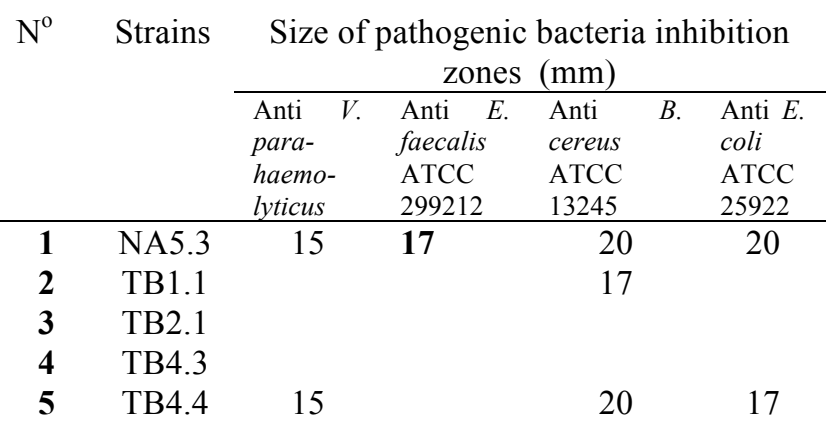

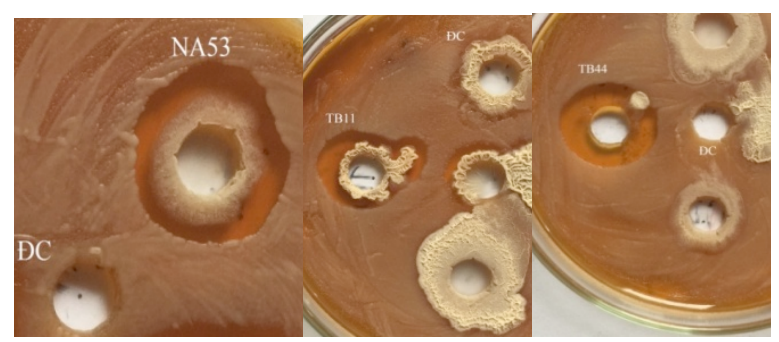

Figure 5. Anti B cereus ATCC 13245

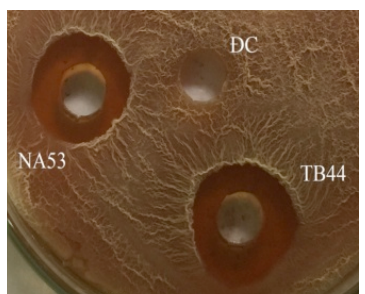

Figure 6. Anti V. parahaemolyticus

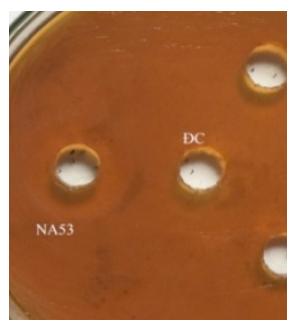

Figure 7. Anti E. faecalis ATCC 299212 


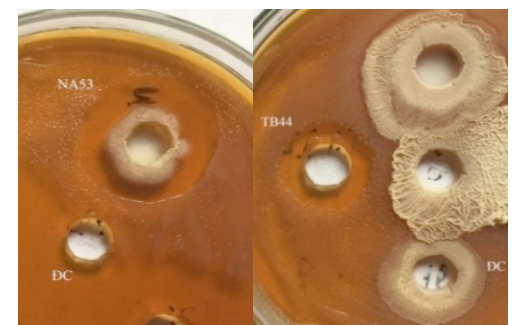

Figure 8. Anti E. coli ATCC 25922

\subsection{Effect of pH on biofilm formation of isolates}

Effect of varying $\mathrm{pH}$ on the biofilm formation of the isolated strains were investigated. From Fig. 9 shown that, all selected bacteria strains TB 2.1; TB 4.3; TB 4.4 and NA 5.3 could form biofilm at wide $\mathrm{pH}$ range from $\mathrm{pH} 2$ to $\mathrm{pH} 10$. They were the best biofilm formation in $\mathrm{pH} 6-8$ and weaker in $\mathrm{pH} 10$, NA5.3 was the most biofilm formation in this $\mathrm{pH}$. These bacteria can form the biofilm quite well at $\mathrm{pH} 2-4$. This is very important characteristic because they can survive in the intestines of shrimp to perform their role of food metabolism.

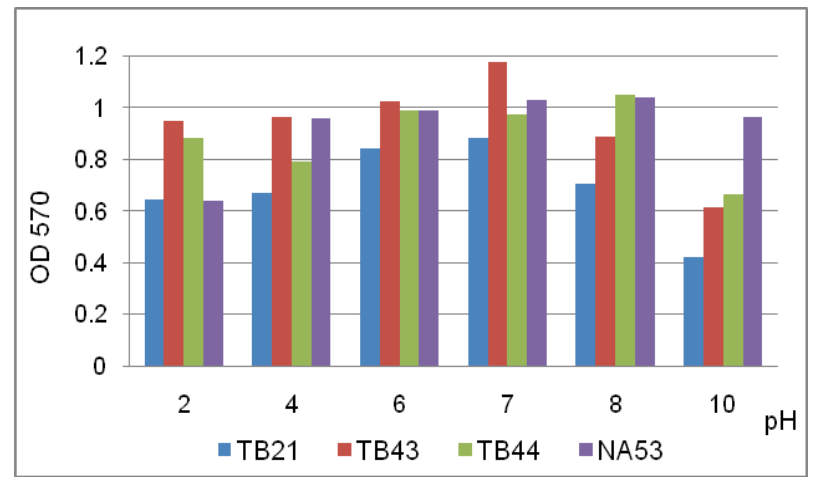

Figure 9. Effect of $\mathrm{pH}$ on the bioflm formation of the selected strains

\subsection{Effect of temperature on biofilm formation of isolates}

Effect of varying temperature on the biofilm formation of the isolated bacterial strains were investigated. The optimal temperatures for the biofilm formation of selected strains were $30-37^{\circ} \mathrm{C}$, in which TB4.4 and NA5.3 strains had biofilm formation higher than the others. Their biofilm formation was below at $5-10^{\circ} \mathrm{C}$. The results also showed that, the selected strains still well formed biofilm at $45^{\circ} \mathrm{C}$ This is a quite important characteristic for the purpose of soybean fermentation and can press the pellets at high temperatures for livestock feed (Fig.10).

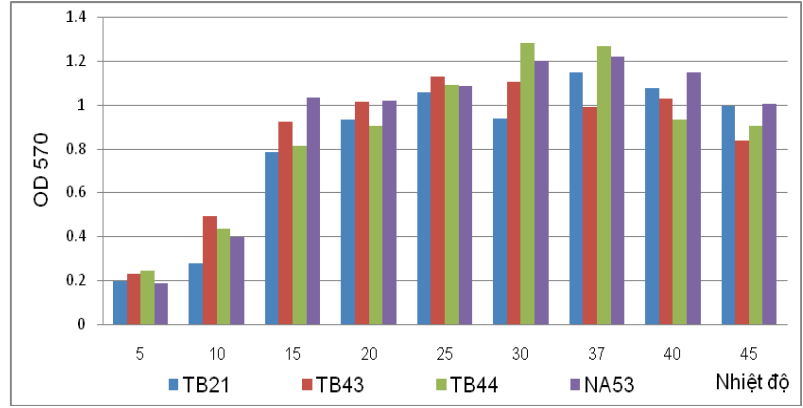

Figure 10. Effect of temperature on biofilm forming capacity of the selected strain

\subsection{Effect of salt ( $\mathrm{NaCl})$ on biofilm formation of isolates}

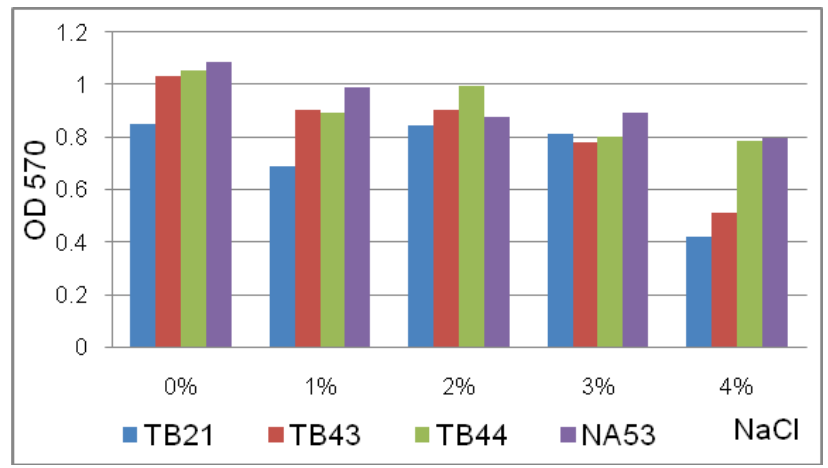

Figure 11. Effect of salt concentrations $(\mathrm{NaCl})$ on the biofilm formation of the isolates

Salinity is known to affect the metabolic activity of bacteria, might be reducing microbial growth. Therefore, in this study, effect of salt concentrations $(\mathrm{NaCl})$ on biofilm formation capacity of the isolated strains was also investigated. The result was presented in Fig. 11.

All isolates formed highest biofilm in the culture medium without $\mathrm{NaCl}$ (Fig.11). All of the strains could form biofilm higher at concentration of $\mathrm{NaCl} 1 \%-3 \%$ than at concentration $\mathrm{NaCl} 4 \%$ but $\mathrm{NA5.3}$ and $\mathrm{TB} 4.4$ strains still well formed biofilm at $\mathrm{NaCl} 4 \%$.

\subsection{Effect of bile salt on biofilm formation of isolates}

Bile acids are considered anti-bacterial agents in the gastrointestinal tract, protect the intestines. Therefore, probiotic microorganism is affected by bile salts through the small intestine. In the small intestine, where bile secretion may have the highest concentration of about $2 \%$. The viability in bile acid solution is an important property of the probiotic microorganism.

In this result, all four strains were capable of producing biofilms at concentrations of bile salts from $0.5-2 \%$ (Fig.12). This result indicated that the strains could grow well in the stomach of the host by biofilm formation process. 


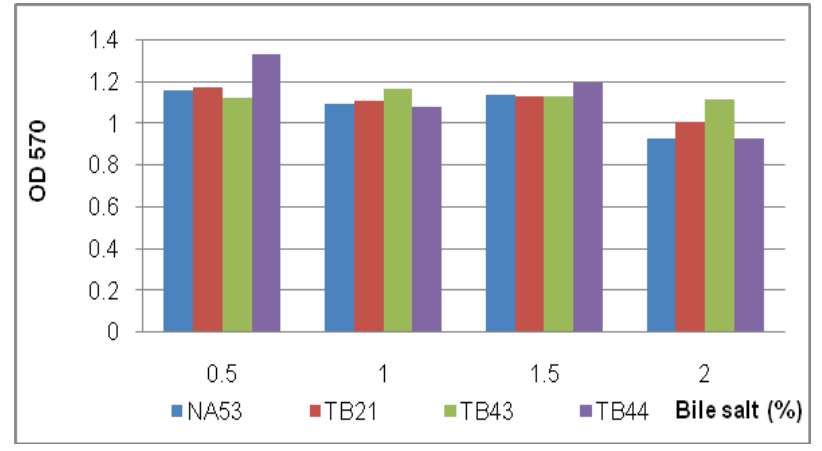

Figure 12. Effect of bile salt concentrations on the biofilm formation of the isolates

\subsection{Fermentation of soybean meal}

Four strains NA5.3; TB2.1; TB4.3 TB4.4 had suitable properties to purpose of soybean fermentation, this result is the basis for forming bio-products using as feed for livestock.

These four strains have been shown to be non-resistant each other (results not shown) so they can be used as multicell for solid fermentation with soybean meal substrate

Using soybean meal as attachment substrates for solid fermentation process. Bacterial biomass was breeding up to $10^{8} \mathrm{CFU} / \mathrm{L}$ and mixed with soybean meal (material and method section).

The substrates were suitable to make product, cell density before and after incubation were $10.10^{6}$ and $45.10^{11} \mathrm{CFU} / \mathrm{g}$, respectively.

To confirm the quality and effectiveness of fermentation products, further research is needed to create a perfect biological product for feeding aquaculture.

\section{Conclusion}

Nine strains NA5.3; TB1.1; TB2.1; TB2.3; TB2.4; TB4.3; TB 4.4; TB 5.1 and TC 1.1 were isolated that have the ability of producing digestive enzymes such as amylase, protease and cellulose

Five strains NA5.3; TB2.1; TB4.3; TB 4.4 and TB 5.1 formed the higher biofilm than the other and three strains NA5.3; TB11; TB 4.4 has anti-pathogenic bacteria capacity

Four strains NA5.3; TB2.1; TB4.3 TB4.4 were estimated the effect on physiological and biochemical conditions on their biofilm formation: suitable conditions were at $\mathrm{pH}$ 68 ; temperatures $30-37^{\circ} \mathrm{C}$; $\mathrm{NaCl}$ concentration $0-3 \%$, bile salt concentration $0,5-2 \%$.

Growth of selected strains in solid fermentation process very well, bacterial populations after fermentation was $10^{11} \mathrm{CFU} / \mathrm{g}$.

Acknowledgement: The funding was provided by the Research Foundation of the Institute of Biotechnology with the title "Fermentation of soybean meal from micro- organism biofilm formation to produce the probiotic supplement the feed for shrimp", coded 18-01-2018.

\section{References}

[1] Goebel, K. P., \& Stein, H. H. (2011). Ileal digestibility of amino acids in conventional and low-Kunitz soybean products fed to weanling pigs. AsianAustralas. J. Anim.Sci, 24, 88-95.

[2] Gu, C., Pan, H., Sun, Z., \& Qin, G. (2010). Effect of soybean variety on anti-nutritional factors content, and growth performance and nutrients metabolism in rat. Int. J. Mol. Sci. 11(3), 1048-56.

[3] Hirabayashi, M., T. Matsui, H. Yano, and T. Nakajima. 1998. Fermentation of soybean meal with Aspergillus usamii reduces phosphorus excretion in chicks. Poult. Sci. 77, 552-556.

[4] Hong Ha, Duc LH and Cuttin SM (2005) The use of bacterial spore formers as probiotics. FEMS Microbiol. Review 29, 813-835

[5] Hong, K. J., C. H. Lee, and S. W. Kim. 2004. Aspergillus oryzae 3.042GB-107 fermentation improves nutritional quality offood soybeans and feed soybean meals. J. Med. Food 7, 430-434.

[6] Jayasree L., Janakiram P., and Madhavi R. (2006), Characterization of Vibrio spp. Associated with Diseased Shrimp from Culture Ponds of Andhra Pradesh (India), Journal of the World Aquaculture Society $37(4), 523$.

[7] Lena, D. G., E. Patroni, and G. B. Quaglia. 1997. Improving the nutritional value of wheat bran by a white rot fungus. Int. J. Food Sci. Technol. 32, 513519.

[8] Liener, I. E. 1994. Implications of antinutritional components in soybean foods. Crit. Rev. Food Sci. Nutr. 34, 31-67.

[9] Mohamed JA, Huang W, Nallapareddy SR, Teng F, Murray BE (2004) Influence of origin of isolates, especially endocarditis isolates and various genes on biofilm formation by Enterococcus faecalis. Infect Immun 72, 3658-63.

[10] Nguyễn Lân Dũng dịch (1983) Thực tập vi sinh vật học. NXB Đại học và Trung học chuyên nghiệp, Hà Nội. Tr: 75-79.

[11] Perez-Maldonado, R. A., Mannion, P. F., \& Farrell, D. J. (2003). Effects of heat treatment on the nutritional value of raw soybean selected for low trypsin inhibitor activity. British Poultry Science, 44(2), 299-308.

[12] Rigo, E., J. L. Ninow, M. Di Luccio, J. V. Oliveira, A. E. Polloni, D. Remonatto, F. Arbter, R. Vardanega, D. de Oliveira, and H. Treichel. 2010. Lipase production by solid fermentation of soybean meal with different supplements. LWT-Food Sci. Technol. 43, 1132-1137.

[13] Rivas MO, Vargas P, Riquelme CE (2010) Interactions of Botryococcus braunii cultures with bacterial 
biofilms. Microbial Ecology 60(3), 628-635.

[14] Schneema Schneeman, B. O., \& Gallaher, D. (1986). Nutritional and Toxicological Significance of Enzyme Inhibitors in Foods. (M. Friedman, Ed.) (Vol. 199). Boston, MA: Springer US. doi:10.1007/978-14757-0022-0

[15] Singh, K., C. J. Linden, E. J. Johnson, and P. R. Tengerdy. 1990. Bioconversion of wheat straw to animal feed by solid substrate fermentation or ensiling. Indian J. Microbiol. 30, 201-208.

[16] Song, Y. S., J. Frias, C. Martinez-Villaluenga, C. Vidal-Valdeverde, and E. G. de Mejia. 2008. Immunoreactivity reduction of soybean meal by fermentation, effect on amino acid composition and antigenicity of commercial soy products. Food Chem. 108, 571-581.

[17] Sun, P., Li, D., Dong, B., Qiao, S., \& Ma, X. (2008). Effects of soybean glycinin on performance and immune function in early weaned pigs. Archives of
Animal Nutrition, 62(4), 313-321.

[18] Teng, D., M. Gao, Y. Yang, B. Liu, Z. Tian, and J. Wang. 2012. Bio-modification of soybean meal with Bacillus subtilis or Aspergillus oryzae. Biocatal. Agric. Biotechnol. 1, 32-38.

[19] Trần Thanh Thủy (1999), Hướng dẫn thực hành vi sinh vật học, NXB Giáo dục, tr. 45-56, 97-102,163171.

[20] Yang, YX., Kim YG., Lohakare JD., Yun JH., Lee JK., Kwon MS., Park JK., Choi JY., and Chae BJ. (2007). Comparative efficacy of different soy protein sources on growth performance, nutrient digestibility, and intestinal morphology in weaned pigs. Asian Australas. J. Anim. Sci. 20, 775-783.

[21] Yuan L, Chang J, Yin Q, Lu M, Di Y, Wang P, Wang Z, Wang E, Lu F, (2017), Fermented soybean meal improves the growth performance, nutrient digestibility, and microbial flora in piglets. Animal Nutrition 3, 19-24. 